\section{Et klart budskap til morgendagens leger!}

Myskja A.

På vei mot en integrert medisin

En innføring i komplementær og alternativ behandling. $310 \mathrm{~s}$, tab, ill. Bergen:

Fagbokforlaget, 2008. Pris NOK 325

ISBN 978-82-450-0240-9

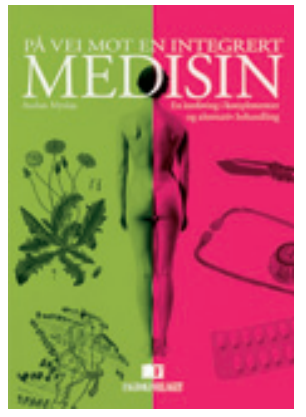

Alternativ medisin

har i Norge, som

i en rekke andre europeiske land, hatt en voldsom fremvekst etter krigen. Fra å være et tilbud til de få utført av en håndfull behandlere er det $i$ dag et bredt tilbud over det ganske land. Helsepersonells holdning til alternativ medisin har også endret seg over tid. Fra å ha inntatt en klar avvisende holdning til slik behandling har mange leger inntatt en mer nøytral posisjon der man mer eller mindre stilltiende aksepterer alternative behandlingsformer som et område der pasienten primært foretar egne valg. Fortsatt er det få leger som aktivt henviser til alternative behandlere. Et unntak er akupunktur hvor man har tall på at hele $65 \%$ av legene henviser sine pasienter til slik behandling. Selv om interessen er økende $\mathrm{i}$ befolkningen, har legenes kunnskaper om alternativ behandling ikke økt i samme grad. Mange kolleger har svært mangelfull innsikt i hva som bedrives av komplementær medisin og alternativ behandling.

$P a ̊$ vei mot en integrert medisin gir på en liketil og grei måte innsikt i dette fagfeltet. Forfatteren og legen Audun Myskja har i over 20 år beskjeftiget seg med fagfeltet og har skrevet flere bøker om ulike temaer innen alternativ medisin. Han gir en klar historisk fremstilling av folkemedisinens fremvekst og integrering i skolemedisinen. Vi tas med inn i diskusjonen om hva som skiller komplementær fra alternativ behandling. Ikke alle leger har fullgod kunnskap om dette emnet. Forfatteren gir en kortfattet, men klar oversikt over ulike terapiformer, hva som virker, og hva som brukes i praksis, og hvem som bruker det. Videre avsanner han en del myter om alternativ behandling, og henviser til forskningsbaserte funn i litteraturen. I et velskrevet kapittel omtales placeboeffekten og håpets fysiologi som alle leger bør kjenne til. Legestanden byr ubevisst også på placeboeffekt i mange av sine gjerninger, og burde i større grad være bevisst på dette og kanskje utnytte denne effekten i større grad i utøvelse av legekunsten.

I et visjonært kapittel gir forfatteren uttrykk for status nå og utviklingen fremover, og slår fast at utviklingen har gått langsomt her hjemme. Legene burde i langt større grad interessere seg for hvor og hvorfor pasientene våre kjøper seg ulike tjenester på behandlermarkedet. I dette omfattende helsemarkedet utgjør legebehandling bare en liten del. Ved å skaffe oss bedre innsikt i dette vil vi i større grad være i stand til å forstå våre pasienters handlinger og atferd.

Boken er velskrevet og språket er klart og tydelig. Fremstillingen bærer preg av forfatterens solide kunnskaper innen feltet. I en kortfattet form gis det en utmerket oversikt over fagfeltet, og boken egner seg således til å leses fra perm til perm for den vitebegjærlige lege. Den burde være et must for alle som driver praksis, spesielt våre unge kolleger som lett kommer i unødig harde diskusjoner med pasienter om hva som er til pasientens beste. Med litt mer kunnskap i bagasjen vil slike diskusjoner bli mer fruktbare. Den anbefales på det varmeste.

\section{Aage Bjertnæs}

Risvollan legesenter

Trondheim

\section{Mye godt om høyt blodtrykk}

Blomhoff R, Iversen PO, Thuesen NP. Hjelp jeg har fått høyt blodtrykk! Hva nå?

144 s, tab, ill. Oslo: Birkeland Publications, 2007. Pris NOK 250

ISBN 978-82-997423-1-3

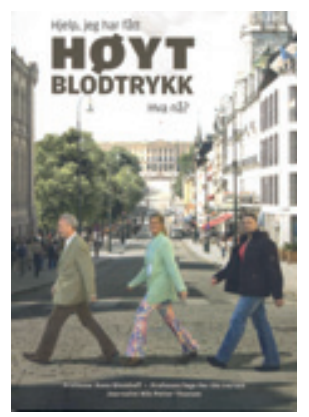

Forfatterne henvender seg til helsepersonell og til befolkningen generelt, og har som målsetting å stimulere til forebyggende tiltak mot høyt blodtrykk. Boken er kanskje mest relevant for pasienter som har

fått påvist hypertensjon.

Første halvdel er deskriptiv om blodtrykkssykdom. Denne delen tar utgangspunkt $i$ at den ene forfatteren får påvist høyt blodtrykk som debuterer med hjertesvikt. Andre halvdel er viet forebyggende kostholds- og andre livsstilsråd. Hvert kapittel gjengir sentrale referanser om de berørte temaene. Det gjør lesingen mer interessant for helseprofesjonene, og tjener som en viktig stimulans til videre fordypning for den som er interessert.

Boken har en svært leseverdig form, med oversiktlig inndeling av stoffet og et lett begripelig språk. Teksten er komplettert med fine illustrasjoner og fotografier som gjør stoffet mer interessant. Referansene som følger hvert kapittel er velvalgte og dokumenterer stoffet på en god måte. Stort sett er fremstillingen saklig og balansert.
Jeg har to innvendinger mot presentasjonen. Den første er at utgangspunktet (sykehistorien om hjertesvikt) dramatiserer stoffet i unødig grad. Et begrep som «den tause morder» som hjemsøker $90 \%$ av befolkningen, er unødig dramatisk. De fleste mennesker med høyt blodtrykk har en ikkesymptomatisk tilstand, som gir dem en statistisk mer-risiko for hjerte- og karsykdom, som ikke er dramatisk. Spesielt gjelder dette dersom det høye trykket ikke er ledsaget av andre risikofaktorer. Den andre innvendingen er at vektleggingen av ASCOT- og PROGRESS-studiene i avslutningskapitlet, kan fremstå som selektert rapportering.

Bortsett fra disse påpekningene er dette en leseverdig opplysningsbok for pasienter og pårørende. Helsepersonell kan bruke den som dokumentasjonskilde, spesielt for å få oversikt over og innføring i sentrale referanser om sammenhengen mellom livsstil og blodtrykk og dokumentasjon om livsstilstiltak.

\section{Eivind Meland}

Seksjon for allmennmedisin Institutt for samfunnsmedisinske fag Universitetet i Bergen

\section{Den store boken i krigskirurgi, til faglig inspirasjon og til ettertanke}

\author{
Nessen SC, Lounsbury DE, Hetz SP, red. \\ War surgery in Afghanistan and Iraq \\ A series of cases, 2003-2007. 442 s, ill. \\ Washington, D.C.: Borden Institute, Walter Reed \\ Army Medical Center, 2008. Pris USD 99 \\ ISBN 978-0-9818-2280-8
}

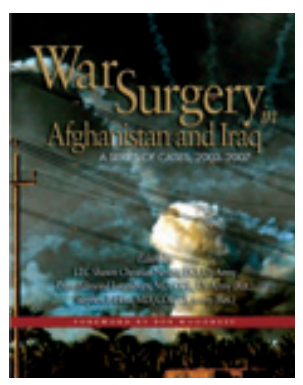

Soldaten skal ha skadebehandling på høyde med sivilt nivå. I de pågående krigene har den amerikanske sanitet vist at avansert kirurgi lar seg gjennomføre nær kamphandlingene.

53 bidragsytere fremlegger kasuistikker fra Afghanistan og Irak. 15 profilerte spesialister bidrar med kapitler om nye behandlingsmetoder. I disse dager har alle digitalkameraet lett tilgjengelig. Det har gitt en enestående dokumentasjon. Hvert tilfelle presenteres slik man opplevde det. Ikke alltid går det bra. Hver pasienthistorie er ledsaget av en diskusjon om hva man kan lære, hva som skal være første nødbehandling og hva de medisinske følgene er. Det henvises til kapitler i det amerikanske forsvarets krigskirurgimanual hvor man kan lese mer om den aktuelle skadetypen (1). 
Saniteten i Norge er ikke ubetinget enig i alt. Dette er ikke en lærebok, men rapporter fra det virkelige liv. Taktisk turniké har sin indikasjon, men skal ikke være blind rutinebehandling (2). På Krigskirurgikurset lærer norske kirurger median sternotomi for å få kontroll over venstre a. subclavia, ikke lateral torakotomi. Lokale hemostatika konkurrerer med god sårpakking og er ikke innført i Forsvaret.

Transfusjon av erytrocytter og plasma $i$ forholdet 1:1 bedrer resultatene ved store blødninger (3). Nytappet fullblod er det beste tilbudet ved massive blødninger (Walking blood bank). Det er i samsvar med norsk doktrine. Det endelige vitenskapelige bevis på effekten av rekombinant koagulasjonsfaktor VIIa mangler, men tendensen til bedret hemostase er klar.

Kasuistikkene demonstrerer hemostatisk nødkirurgi som livreddende, med pakking av blødninger, med karshunter og med spjelking ved ekstremitetsskader. Det vises til faren ved avventende holdning og faren ved omstendelig kirurgi på pasienter i ustabil tilstand. Det er tallrike, gode tekniske råd.

Boken er solid innbundet i stort format. Det er illustrative strektegninger, røntgenbilder og CT-bilder, men fremfor alt tallrike fargebilder av pasientene. Bildene er groteske, men instruktive og velbegrunnede. Innimellom er det andre bilder, til dels fremragende journalistisk, av sanitetsaktiviteter fra kampsonene.

Det gikk rykter om at boken ble forsøkt holdt unna alminnelig utbredelse da den kunne tenkes brukt i propaganda mot de pågående krigene. Det kan den, men den er anbefalt fritt solgt av den amerikanske hærs sanitetssjef.

Boken vil bli kjøpt inn av Forsvarets Sanitet til alle de kirurgiske installasjonene. Den kan anbefales til akuttsykehus hvor man risikerer å måtte ta imot skudd-, stikkog eksplosjonsskader og hvor man generelt strever med problemene rundt hemostatisk nødkirurgi og væske- og blodresuscitering.

\section{Johan Pillgram-Larsen}

Forsvarets Sanitet

Thoraxkirurgisk avdeling

Ullevål universitetssykehus

Litteratur

1. Emergency war surgery, Third United States Revision. Washington, D.C.: Department of the Army, Office of the Surgeon General, Borden Institute, 2003

2. Husum H, Gilbert M, Wisborg T et al. Prehospital tourniquets: There should be no controversy. Jrauma 2004: 56:214-5.

3. Gaarder C, Næss PA, Skaga NO et al. Skyldes redusert dødelighet ved alvorlige blødninger hos traumepasienter endret transfusjonspraksis? Abstrakt 262. I: Vasli S, red. De norske kirurgiske foreninger, vitenskapelige forhandlinger - Oslo, 2008. www.brataas.no/hostmotet/28-Abstrakt253-263.pdf.(29.1.2009).

\section{Pensum for ein fastlegeminister}

Verdens helseorganisasjon Primary health care now more than ever

The world health report 2008. 119 s, tab, ill. Genève: WHO, 2008. Pris CHF 20

ISBN 978-92-4-156373-4

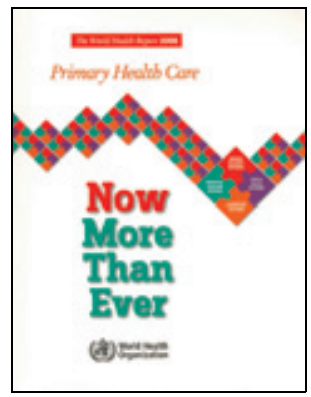

Dette er boka som på 100 sider i tiltalande layout klarer å overbevise lesaren om at tittelen held mål: Det er like viktig som for å bygge helsetenesta på ein grunnmur av primærhelsetenester, både $\mathrm{i}$ fattige og i rike land. Og tidspunktet kunne ikkje vore betre, sett med norske auge. Hausten 2008 har fastlegane forsøkt å få vind i segla sine, med internasjonal støtte (1). Og like før jul kom Helsedirektoratet med si tilråding om trong for 2700 nye fastlegar $(2,3)$, ei tilråding helseministeren i prinsippet slutta seg til.

WHOs helserapport for året 2008 har altså primærhelsetenesta som tema, ikkje unaturleg ved 30-årsmarkeringa for Alma Ata-erklæringa (4). Dei seks oversiktlege kapitla er rikt illusterte med figurar og tabellar. Dette er boka som på grunnleggande vis og med oppdaterte referansar, grunngjev kvifor ein skal satse på primærhelsetenesta. Eg var skeptisk til om alle eksempla frå fattige land og land med mykje dårlegare helseteneste enn vi har, kunne fungere hos oss. Men det gjer dei så det susar. Her er prinsippa så generelle og utviklingstendensane så allmenne, at vi kjenner oss godt igjen. Rapporten slår fast at utan politikk og fast styring for å hindre det, er det tre viktige tendensar som underminerer primærhelsetenesta i alle land: Offentleg helseteneste med sjukehus og spesialistar i fokus, fragmentering, det vil seie fokus på enkeltområde framfor samla behov, og uregulert kommersialisering av helsetenester.

Her klarer ein å formidle at allmennpraksis eigentleg handlar om å sette pasienten i sentrum, inkludert kva det verkeleg kan bety for folk å ha den samme legen over tid. Ein lege som opparbeider seg kunnskap og erfaring om pasientane sine, opparbeider seg også ofte ein tillit som har stor verdi $\mathrm{i}$ behandlingsrelasjonen. Og WHO argumenterer faktisk sterkt for prinsippet om fastlegeordning, enten på geografisk eller personleg basis.

Denne boka er nyttig for legar i allmennpraksis, for samfunnsmedisinarar på alle nivå og for dei som er premissleverandørar gjennom faglege organisasjonar eller $\mathrm{i}$ forvaltninga. Og den tilhøyrer kjernepensumet for ein fastlegeminister og rådgjevarane hans.

\section{Steinar Hunskår}

Seksjon for allmennmedisin

Institutt for samfunnsmedisinske fag

Universitetet i Bergen

\section{Litteratur \\ 1. Sundar T. Sats på primærhelsetjenesten! Tidsskr Nor Legeforen 2008; 128: 2765 \\ 2. Bakkerud J. Sterk primærhelsetjeneste best og billigst. Helsedirektoratet 10.12.2008 www helse- direktoratet.no/fagnytt/sterk_prim_rhelsetjeneste best_og_billigst_298134 (2.1.2009). \\ 3. Helsedirektoratet. Utviklingsstrategi for legetje- nestene i kommunene. IS-1652. Oslo: Helsedirek- toratet, 2008. www helsedirektoratet.no/vp/multi- media/archive/00089/Utviklingsstrategi_f_ 89669a.pdf (12.1.2009) \\ 4. Declaration of Alma-Ata. International Conference on Primary Health Care, Alma-Ata, USSR, 6-12 September 1978. www.who.int/hpr/NPH/docs/ declaration_almaata.pdf (13.1. 2009).}

\section{Kort og godt om cøliaki}

Fasano A, Troncone R, Branski D, red. Frontiers in celiac disease

222 s, tab, ill. Basel: Karger, 2008. Pris CHF 178 ISBN 978-3-8055-8526-2

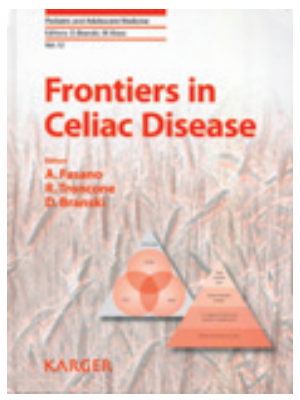

Dette er volum 12 i Kargers serie om Pediatric and adolescent medicine der man i de foregående bøkene har tatt for seg overvekt, diabetes og thyreoideasykdommer. Hvert volum kan selvfølgelig leses separat.

Hvert av de 23 kapitlene er skrevet av internasjonale eksperter. Målgruppen er alle som arbeider med og er interessert i cøliaki.

Stoffet er velillustrert og godt språklig fremstilt. Flere av illustrasjonene belyser emner som knapt tidligere er vist innen dette feltet. Kapitlene er av variabel lengde, og har ulikt antall referanser. Bare i ett av kapitlene er det listet opp svært mange referanser, de øvrige har et relevant og begrenset utvalg.

Det er få andre felter innen human biologi og medisin der det de siste årene har skjedd like store fremskritt som dem vi har sett innen vår forståelse av cøliaki. Forfatterne har alle vært sentrale i denne utviklingen. Emner som er omtalt er bl.a. epidemiologi, patogenese, klinisk presentasjon, og diagnostikk og behandling av cøliaki. Nåværende retningslinjer for diagnostikk av cøliaki hos barn og voksne fra henholdsvis The European Society of Paediatric Gastroenterology, Hepatology and Nutrition (ESPGHAN)/ North American Society for Pediatric Gastroenterology, Hepatology and Nutrition (NASPGHAN) 